\title{
Relationship Marketing Implementation of Commitment and Satisfaction in Inpatients in Class III of Buleleng District Hospital
}

Qamariyah
Magister of Public Health Program of
Institut Ilmu Kesehatan STRADA
Indonesia
Email:
indahsintya88@gmail.com

Received: October 12, 2019

Accepted : February 13, 2020

Published : May 12, 2020

\begin{abstract}
Commitment and patient satisfaction in hospital services is a priority of the hospital, especially in the inpatient room. Therefore we need methods to make this happen. The purpose of this study is the Effect of Relationship Marketing Implementation on Satisfaction and Commitment in Inpatients in Class III of Buleleng District Hospital. The research method was observational analytic with cross-sectional design. The population is inpatients in class III with a sample of 174 respondents taken by random sampling techniques according to criteria. Using logistic regression statistical analysis. The results of this study are the influence of Relationship Marketing Implementation on the Satisfaction and Commitment of Inpatients in Class III of Buleleng District Hospital, this is indicated by the $\mathrm{p}$-value $<\alpha 0.05$ and hospital service factors as well as the characteristics of respondents affect the Satisfaction and Commitment of Inpatients Inpatient in Class III of Buleleng Regency Hospital. In conclusion, the implementation of Relationship Marketing 5 times has the opportunity to increase Satisfaction and Commitment in Inpatients in Class III of Buleleng Regency Hospital, the characteristics of respondents 7 times have the opportunity to increase Satisfaction and Commitment in Inpatients in Class III of RSUD in Buleleng Regency and hospital services 8 times have the opportunity to increase Satisfaction and Commitment to Inpatients in Class III of Buleleng District Hospital. Relationship Marketing implementation concluded that it was good to be implemented in increasing Commitment and Satisfaction in Inpatients in Class III of Buleleng District Hospital.
\end{abstract}

Keywords: Implementation, Relationship Marketing, Commitment and Satisfaction

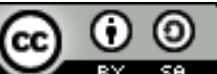

This is an open-acces article distributed under the terms of the Creative Commons Attribution-ShareAlike 4.0 International License. 


\section{INTRODUCTION}

The need for companies to improve the quality of products or services and customer satisfaction is increasingly greater along with free trade that is open in the era of globalization. Competition is getting stronger and only quality services produced by quality human resources are able to survive, therefore the achievement of quality products and services is the center of attention of the hospital. Good service quality is a benchmark for customer satisfaction and loyalty to re-use services. A service is considered satisfactory if the service can meet the needs, desires and expectations of customers. Conversely, if the customer feels dissatisfied with a service provided it will have an impact on reducing patient visits to a hospital. Customers will look for products, in the form of goods or services from companies that can provide the best service to him (Assuari, 2003).

Customer focus or service focused on customers must base the mindset (mindset) of providers in the health sector. Patient-focused services are the center of attention for hospitals, so there is a need for marketing services at hospitals in an effort to improve hospital services where the desired outcome is patient satisfaction with hospital services. The hospital is one of the companies that is demanded to be able to win the competition. In addition, the hospital is an effort to avoid and prevent the demands of the community in accordance with Law No.8 of 1999 concerning consumer protection. Improved services in order to increase patient satisfaction, those who are competent with hospitals are always looking for innovative efforts to improve the quality of hospital health services, among others, by getting an ISO 9000 certificate. decreased number of patient visits.

Buleleng Regional General Hospital (hereinafter referred to as Buleleng Regional Hospital) as a type $\mathrm{C}$ hospital under the auspices of the Buleleng Regency Health Office. This imbalance results in complaints and even complaints from the public, such as the attitude of officers who are not friendly, convoluted procedures, friendliness of doctors and nurses, doctor's time to visit is not on time, nurses who are stiff when asked, improper service rates and cleanliness and comfort of an inpatient room.

Based on the background presented above, the performance of Buleleng Regional Hospital has continued to improve over the past 3 years and there has been an efficiency in services but the quality of service in Buleleng Regional Hospital is still lacking. Based on this, the problem that can be raised in this study is the lack of satisfaction of inpatients in Buleleng Regional Hospital with a score of 3.52 or included in the moderate category.

Problem Formulation: The formulation of the problem in this study is: Is there an Effect of Relationship Marketing Implementation on Satisfaction and Commitment in Inpatients in Class III General Hospital of Buleleng Regency?

Research Objectives: Analyzing the Effect of Relationship Marketing on Commitment and Satisfaction in Inpatients in Class III of Buleleng District Hospital

Specific Objectives: (1) Analyze the effect of the implementation of Relationship Marketing on patient characteristics in inpatients in class III of Buleleng District Hospital. (2) Analyzing the effect of relationship marketing implementation on commitment to inpatients in class III of Buleleng Regency Hospital (3) Analyzing the effect of relationship marketing implementation on satisfaction of inpatients in class III of Buleleng Regency Hospital. (4) Analyzing the effect of implementing relationship marketing on hospital services for Inpatients in Class III of Buleleng District Hospital.

Research Benefits: (1) For researchers, applying public health knowledge, especially marketing and financial management of health services (2) For the Faculty of Public Health, in addition to knowledge and research discourse and research, especially in marketing and finance. (3) The results of this study can be information material for other researchers who will conduct research on marketing strategies in hospital services, (4) For Buleleng Regional Hospital, the results of this study serve as input for management in an effort to improve inpatient satisfaction in Buleleng Regional Hospital.

\section{METHODS}

This type of research is analytic observational research, in which the researcher only observes, without providing interventions to the variables to be studied to determine the causal relationship between variables. The form of relationships can be in the form of differences, relationships or influences (Supriyanto, 2011). The population of this study is to use the average number of patient visits in class III inpatients within a period of 3 months where class III consists of: room for as much as 114 / month, Lely 1 for 120 / month for patients, then operating room (Cambodia) for 145 / month, Jasmine 
II room is 86 / month based on the average monthly IRNA patient data in 2018 at the Buleleng Regional General Hospital. When the study was conducted on October 1 to December 12 in 2019. Data collection was carried out for two months, starting in October 2019. The location of this study was Class III Inpatient at Buleleng Regional Hospital.

\section{Data Collection Techniques and Procedures}

The data used in this study are primary data and secondary data. Primary data come from the answers filled in by respondents on the questionnaire sheet and the results of interviews conducted by researchers after the respondents filled out the questionnaire. While the secondary data came from the profile of the Buleleng Regional Hospital which was used as the research location. Before collecting primary data, the research instrument will be tested for validity and reliability first. According to Azwar (2000) the instrument or questionnaire is said to be valid if it is known by comparing the Pearson product moment correlation index with a significance level of 5\%. While the instrument or questionnaire is said to be reliable if the questionnaire still shows consistent measurement results when repeated measurements are made to different groups of individuals. Reliability measurement using Cronbach's alpha. The instrument is said to be reliable if the Cronbach's alpha value $>0.6$.

The research instrument was tested to inpatients at Buleleng Regional Hospital on August 11, 2019. After the validity test, the researcher tested the reliability of the instrument in order to know the consistency of the research instrument when repeated measurements were made on different groups of individuals. The validity test results show Pearson correlation values of more than 5\% (0.05) so that all question items are declared valid. While the reliability test results obtained cronbach's alpha value is more than 0.6 so that the questions in all variables are declared reliable.

Data analysis : After the primary data is collected, the researcher processes the data using software with the help of a computer. The purpose of this study was to analyze the Implementation of Relationship Marketing Towards Commitment and Satisfaction in Inpatients in Class III of Buleleng District Hospital. Therefore, researchers use Logistics Regression

\section{RESULTS}

Research sites: Buleleng Regency Hospital has 3 Main Buildings, namely: The main building located in the southern part is a building consisting of 4 floors including the RSUD offices in the main Building on the 4th floor. The third building is an inpatient building. The hospital has 153 midwives, 257 nurses, 36 specialist doctors, and 26 general practitioners. In the main building (I) consists of inpatient rooms, emergency room and offices are on the fourth floor.

Table 4.1 Distribution of Human Resources in class III inpatients in RSUD Kab. Buleleng in 2019.

\begin{tabular}{|l|l|c|}
\hline \multicolumn{1}{|c|}{ Health Workers } & Amount \\
\hline a. & Bachelor Nurshing dan Ners & 68 \\
\hline b. & Bachelor of Public Health & 1 \\
\hline c. & Bachelor Pharmacy/pharmacist & 4 \\
\hline d. & D3 Nurshing & 87 \\
\hline e. & D3 dan D4 Midwifery & 23 \\
\hline f. & D3 Radiographer & 9 \\
\hline g. & D3 Health Analyst & 7 \\
\hline h. & Health of Senior Hight School & 17 \\
\hline i. & Pharmacist assistant & 2 \\
\hline j. & D3 Physioterapist & 2 \\
\hline k. & D3 ATEM & 1 \\
\hline l. & D3 Nutrition & 5 \\
\hline m. & D3 Medical Recorder Amount & 1 \\
\hline & Bachelor of Medical Recorders and Health & 1 \\
\hline & $\quad 228$ \\
\hline
\end{tabular}


Table 4.2 Frequency distribution of characteristic variables including Age, Gender, education, and occupation in class III inpatients of RSUD Kab. Buleleng in 2019

\begin{tabular}{lcc}
\hline Age & & \\
$<20$ Years old & 8 & 4,6 \\
20-45 Years old & 63 & 36,2 \\
$>$ 45 Years old & 103 & 59,2 \\
\hline Total & 174 & 100 \\
& & \\
\hline Gender & 123 & 70,7 \\
Male & 51 & 29,3 \\
Famale & 174 & 100 \\
\hline Total & & \\
& & \\
Education & 11 & 6,3 \\
Education & 77 & 44,3 \\
No School (NS) & 70 & 40,2 \\
Elementary school & 11 & 6,3 \\
Middle School & 5 & 2,9 \\
High school & $\mathbf{1 7 4}$ & $\mathbf{1 0 0}$ \\
\hline Total & & \\
Profession & 26 & 14,9 \\
Does not work & 72 & 91,4 \\
Labor & 17 & 31 \\
General employees & 54 & 2,9 \\
entrepreneur & 5 & $\mathbf{1 0 0}$ \\
& $\mathbf{1 7 4}$ & \\
\hline Total & & \\
\hline
\end{tabular}

Table 4.3 The variable frequency distribution of hospital service factors includes the type of service and Value PPatients in inpatient rooms class III District Hospital. Buleleng in 2019

\begin{tabular}{lcc}
\hline \multicolumn{1}{c}{ Research Variable } & Frequency(f) & Percentage(\%) \\
\hline Service type & & \\
Public / private funds & 10 & 5,7 \\
Personal Ansurance/ & 42 & 24,1 \\
company & 95 & 54,6 \\
Government BPJS & 27 & 15,5 \\
BPJS Mandiri & & 0 \\
Jasa Raharja & 0 & $\mathbf{1 0 0}$ \\
Total & $\mathbf{1 7 4}$ & \\
\hline Patient_value & & 63,8 \\
Well & 111 & 36,2 \\
Enough & \multicolumn{2}{c}{63} \\
Less & \multicolumn{2}{c}{0} \\
\hline \multicolumn{1}{r}{ Total } & $\mathbf{1 7 4}$ & $\mathbf{1 0 0}$ \\
\hline
\end{tabular}


Table 4.4 The Frequency Distribution of Relationship Marketing variables includes Communication, Relationship benefits, shared values and opportunistic inpatients in Class III District Hospital. Buleleng in 2019

\begin{tabular}{lcc}
\hline \multicolumn{1}{c}{ Research Variable } & Frequency(f) & Percentage(\%) \\
\hline Cominication & 127 & \\
Satisfied & 47 & 73 \\
Very Satisfied & $\mathbf{1 7 4}$ & $\mathbf{1 0 0}$ \\
\hline Total & & \\
\hline Relatioship benefit & 116 & 66,7 \\
Satisfied & 58 & 35,3 \\
Very Satisfied & $\mathbf{1 7 4}$ & $\mathbf{1 0 0}$ \\
\hline Total & & \\
\hline Shaed Value & 79 & 45,4 \\
Satisfied & 95 & 54,6 \\
Very Satisfied & $\mathbf{1 7 4}$ & $\mathbf{1 0 0}$ \\
\hline Total & & \\
\hline Opotunistic & 116 & 66,7 \\
Satisfied & 58 & 35,3 \\
Very Satisfied & $\mathbf{1 7 4}$ & $\mathbf{1 0 0}$ \\
\hline Total & &
\end{tabular}

Table 4.5 Frequency Distribution of the Dependent variable includes Commitment and Satisfaction and Patients in inpatient rooms class III District Hospital. Buleleng in 2019

\begin{tabular}{lcc}
\hline \multicolumn{1}{c}{ Research Variable } & Frequency(f) & Percentage(\%) \\
\hline Commitment & 162 & \\
Commitment & 12 & 93,1 \\
Not Commitment & $\mathbf{1 7 4}$ & 6,9 \\
\hline Total & & $\mathbf{1 0 0}$ \\
\hline Satisfaction & 162 & \\
Satisfied & 12 & 93,1 \\
Not Satisfied & $\mathbf{1 7 4}$ & 6,9 \\
\hline Total & & $\mathbf{1 0 0}$ \\
\hline
\end{tabular}


Bivariate Analysis

Table 4.6 Cross Tabulation of Characteristics of Commitments in Inpatients in Class III of Buleleng District Hospital in 2019

\begin{tabular}{|c|c|c|c|}
\hline \multirow[b]{2}{*}{ Characteristic } & \multicolumn{2}{|c|}{ Commitment } & \multirow[b]{2}{*}{ Chi Square } \\
\hline & $\begin{array}{c}\text { Commitment } \\
\text { (f) }\end{array}$ & $\begin{array}{l}\text { Not Commitment } \\
\text { (f) }\end{array}$ & \\
\hline Age & & & $0,048 *$ \\
\hline$<20$ Years old & 8 & 0 & \\
\hline 20-45 Years old & 57 & 6 & \\
\hline$>45$ Years old & 97 & 6 & \\
\hline Total & 162 & 12 & \\
\hline Gender & & & 0,09 \\
\hline Male & 117 & 0 & \\
\hline Famale & 45 & 6 & \\
\hline Total & 162 & 12 & \\
\hline Education & & & $0,03 *$ \\
\hline No School (NS) & 11 & 0 & \\
\hline Elementary school & 73 & 4 & \\
\hline Middle School & 62 & 8 & \\
\hline High school & 11 & 0 & \\
\hline & 5 & 0 & \\
\hline Total & 162 & 12 & \\
\hline Profession & & & $0,008 *$ \\
\hline Does not work & 24 & 2 & \\
\hline Labor & 68 & 4 & \\
\hline General employees & 50 & 4 & \\
\hline entrepreneur & 15 & 2 & \\
\hline & 5 & 0 & \\
\hline Total & 162 & 12 & \\
\hline
\end{tabular}

Table 4.7 Cross Tabulation of Characteristics of Satisfaction of Inpatients in Class III of Buleleng Regency Hospital in 2019

\begin{tabular}{|c|c|c|c|}
\hline \multirow{2}{*}{ Characteristic } & \multicolumn{2}{|c|}{ Satisfaction } & \multirow{2}{*}{ Chi Square } \\
\hline & Satisfied (f) & Not Satisfied (f) & \\
\hline$\overline{\text { Age }}$ & & & $0,048 *$ \\
\hline$<20$ Years old & 8 & 0 & \\
\hline 20-45 Years old & 57 & 6 & \\
\hline$>45$ Years old & 97 & 6 & \\
\hline Total & 162 & 12 & \\
\hline Gender & & & 0,09 \\
\hline Male & 117 & $\begin{array}{l}6 \\
6\end{array}$ & \\
\hline Famale & 45 & 6 & \\
\hline$\overline{\text { Total }}$ & 162 & 12 & \\
\hline
\end{tabular}

Education

$0,03^{*}$ 


\begin{tabular}{lccc} 
No School (NS) & 11 & 0 & \\
Elementary school & 73 & 4 & \\
Middle School & 62 & 8 & $0,008^{*}$ \\
High school & 11 & 0 & \\
& 5 & 0 & \\
\hline Total & $\mathbf{1 6 2}$ & & \\
\hline Profession & & 2 & \\
Does not work & 24 & 4 & \\
Labor & 68 & 4 & \\
General employees & 50 & 2 & \\
entrepreneur & 15 & 0 & $\mathbf{1 2}$ \\
\hline Total & 5 & $\mathbf{1 6 2}$ &
\end{tabular}

Table 4.8 Cross Tabulation of Hospital Services Against Satisfaction of Inpatients in Class III of Buleleng District Hospital in 2019

\begin{tabular}{lccc}
\hline \multicolumn{1}{c}{$\begin{array}{l}\text { Research } \\
\text { Variable }\end{array}$} & \multicolumn{2}{c}{ Satisfaction } & \multirow{2}{*}{ Chi square } \\
\cline { 2 - 3 } & Satisfied & Not Satisfied & \\
\hline Jenis Layanan & & & $0,018^{*}$ \\
$\begin{array}{l}\text { Public / private funds } \\
\text { Personal Ansurance/ }\end{array}$ & 10 & 2 & \\
$\begin{array}{l}\text { company } \\
\text { Government BPJS }\end{array}$ & 42 & 4 & \\
BPJS Mandiri & 80 & 1 & \\
& 20 & 2 & \\
Jasa Raharja & 10 & 3 & $0,002^{*}$ \\
\hline Total & 0 & 0 & \\
\hline Patient_value & $\mathbf{1 6 2}$ & $\mathbf{1 2}$ & \\
Well & 106 & 5 & \\
Enough & 56 & 7 & \\
Less & 0 & 0 & \\
\hline \multicolumn{1}{c}{ Total } & $\mathbf{1 6 2}$ & $\mathbf{1 2}$ & \\
\hline
\end{tabular}


Table 4.9 Cross Tabulation of Hospital Services Against Satisfaction of Inpatients in Class III of Buleleng District Hospital in 2019

\begin{tabular}{|c|c|c|c|}
\hline \multirow{2}{*}{$\begin{array}{l}\text { Research } \\
\text { Variable }\end{array}$} & \multicolumn{2}{|c|}{ Commitment } & \multirow{2}{*}{ Chi square } \\
\hline & Commitment & Not Commitment & \\
\hline \multicolumn{4}{|l|}{ Service type } \\
\hline Public / private funds & 10 & 2 & $0,018^{*}$ \\
\hline Personal Insurance/ & 42 & 4 & \\
\hline company & 80 & 1 & \\
\hline Government BPJS & 20 & 2 & \\
\hline BPJS Mandiri & 10 & 3 & \\
\hline Jasa Raharja & 0 & 0 & \\
\hline Total & 162 & 12 & \\
\hline \multicolumn{4}{|l|}{ Patient_value } \\
\hline Well & 106 & 5 & $0,002 *$ \\
\hline Enough & 56 & 7 & \\
\hline Less & 0 & 0 & \\
\hline Total & 162 & 12 & \\
\hline
\end{tabular}

Table 4.8 Cross Tabulation of Relationship Marketing Implementation of Commitment and Satisfaction in Inpatients in Class III of Buleleng District Hospital in 2019

\begin{tabular}{lccc}
\hline \multicolumn{1}{c}{$\begin{array}{c}\text { Variable } \\
\text { Independent }\end{array}$} & \multicolumn{2}{c}{$\begin{array}{c}\text { Variable Dependent } \\
\text { Commitment } \\
\text { Patient }\end{array}$} & $\begin{array}{c}\text { Satisfaction } \\
\text { Patient }\end{array}$ \\
value) \\
Relationship Marketing & 45 & 42 & $0,003^{*}$ \\
Characteristics & 25 & 38 & 0,346 \\
Hospital Services & 15 & 9 & $0,041^{*}$ \\
\hline Total & 85 & 89 & \\
\hline
\end{tabular}

Table 4.9 Bivariate Analysis Determine the Effect of Relationship Marketing Implementation on Commitment and Satisfaction in Inpatient Patients in Class III of Buleleng District Hospital in 2019

\begin{tabular}{lccc}
\hline \multirow{2}{*}{$\begin{array}{c}\text { Variable } \\
\text { Independent }\end{array}$} & AOR & \multicolumn{2}{c}{$\begin{array}{c}\text { Variable Dependent } \\
\text { (P value-value)* }\end{array}$} \\
\cline { 2 - 4 } & & $\begin{array}{c}\text { Commitment } \\
\text { Patient }\end{array}$ & $\begin{array}{c}\text { Satisfaction } \\
\text { Patient }\end{array}$ \\
\hline Relationship Marketing & 0,050 & 0,020 & 0.000 \\
Characteristics & 0,074 & 0,000 & 0,000 \\
Hospital Services & 0,084 & 0,039 & 0,040 \\
\hline
\end{tabular}

* Logistic Regression statistical test level of Significant 0.05

\section{DISCUSSION}

The Effect of Relationship Marketing Implementation on Commitments in Inpatients in Class III of Buleleng District Hospital.

The results of this study indicate that there is an Effect of Relationship Marketing Implementation on Commitments in Inpatients in Class III of Buleleng District Hospital. In the Relationship Marketing variable includes Communication, Relationship benefits, shaed value and opportunistic inpatients in the District Hospital. Buleleng in 2019 some respondents said they were 
satisfied with the service in the inpatient room in the Cominication component as many as 127 respondents (73\%) expressed satisfaction. Relationship benefits expressed satisfaction as many as 116 respondents (66.7\%), shaed value stated very satisfied as many as 95 respondents $(54.6 \%)$ and opportunistic components expressed satisfaction as many as 116 respondents $(93.1 \%)$. In a further test the results of the data analysis explained that there was an effect of Relationship Marketing Implementation on Commitment and Satisfaction in Inpatients in Class III of Buleleng District Hospital with a p-value commitment of 0.020 and patient satisfaction p-value of 0.000 showing $<\alpha 0.05$ and the value of All Old Ratio (AOR) 0, 050 which means Relationship Marketing 5 times has the opportunity to increase patient commitment and satisfaction.

This is supported by the results of the questionnaire answers filled out by respondents. On the dimension of Relationship Marketing Communication point empathy that most of the respondents gave strongly agree on point empathy consisting of three (3) questions, one of which was paramedics giving a detailed explanation of how to take medication, the results of the examination so that patients can receive and understand. Another important point is that paramedics listen to patient complaints, when invited to speak do not look away and respond to patient complaints. The results of this qualitative study support the results of statistical tests that there is a significant influence on the implementation of relationship marketing on the commitment of inpatients in class III of Buleleng District Hospital. Morgan and Hunt (1994) argue that relationship marketing is all activity in the field of marketing that is directed at creating developing and maintaining success, an exchange relationship between companies. The key to the success of marketing activities is commitment and trust. On the one hand it is possible for buyers and sellers to carry out transactions that are repeated over time that results in longterm relationships in a transactional model. The results of research conducted prove that trust is the basis for inter-company cooperation that will affect the desire to continue long-term relationships. Where in this study the trust (trust) is the satisfaction of inpatients.

This is also influenced by the characteristic factors of respondents including age that most of the age of the respondents are at an average of $>45$ years which means the respondent already has a thorough understanding of the good things that must be experienced. Maturity of respondents who are more mature in thinking and working will be more selective in choosing a place for health services. disease can strike at a young age but when age reaches maturity the symptoms of the disease will begin to be felt. So it is important that hospitals provide priority services to the age of patients who are elderly (Ndubisi, 2007).

\section{The Effect of Relationship Marketing Implementation on Satisfaction in Inpatients in Class III of Buleleng District Hospital}

The results of data analysis explain that there is a significant effect of Relationship Marketing Implementation on Commitment and Satisfaction in Inpatients in Class III of Buleleng District Hospital with the implementation of Relationship Marketing 5 times as likely to increase patient commitment and satisfaction.

The results of the analysis of this study were examined from the results of a questionnaire answered by respondents that on the dimensions of the Relationship Benefits point Emotional and social benefits, the majority of respondents responded strongly agree that the hospital provides convenience in providing services to patients, the hospital provides a waiting room for patient visitors, and paramedics always smile in serving patients. The results of this qualitative analysis provide statistical test results that there is a significant effect of Relationship Marketing Implementation on Patient Satisfaction in class III inpatients in Buleleng Hospital.

Communication in relationship marketing is related to the value obtained by the patient, providing accurate and reliable information as well as information about changes in services offered, and proactive communication when problems occur between the hospital and the patient (Morgan and Hunt, 1994). Patients always want effective communication with the hospital, good communication can certainly increase the patient's commitment to the hospital.

Patients who do not understand the services provided, will begin to ask the officer or the hospital which is the right of the patient. The hospital in this case must provide an explanation in a friendly and appropriate procedure. Therefore opportunistic behavior influences research so that it is used as a variable in this study. The relationship marketing dimension is an embodiment to achieve the goals of 
relationship marketing that can directly affect patient loyalty and satisfaction. Relationship marketing creates a strong relationship between the hospital and the patient, so the hospital can understand the needs and desires of the patient's customers.

\section{Influence of patient characteristics on the implementation of Relationship Marketing in Inpatients in Class III of Buleleng District Hospital.}

The results showed there was an influence of the characteristics of the respondents in this study including age, education, occupation and gender of inpatients in class III Buleleng Hospital. The results found are the respondents in this study found the characteristics of respondents average age $>45$ years as many as 103 respondents (59.2\%), with the majority of male sex as many as 123 respondents $(70.7 \%)$ and education mostly graduated from elementary school as many as 77 respondents (44.3\%). Most respondents work as laborers as many as 72 respondents $(41.4 \%)$. In the test results of the regression effect that the characteristics of respondents 7 times the opportunity to increase patient commitment and patient satisfaction in class III inpatient rooms.

The regional general hospital of Buleleng Regency is a hospital located in the downtown area of the Regency of Buleleng. Health services. disease can strike at a young age but when age reaches maturity the symptoms of the disease will begin to be felt. So it is important that hospitals provide priority services to the age of patients who are elderly (Ndubisi. 2007) Work is also a factor that indirectly requires respondents to get the best service in the hospital. This intention arises when the respondent feels that there is an income in him. To get satisfaction, although an effort is needed by the respondent to get satisfaction and this is very influential on the willingness of hospitalized patients in class III. Families with low economic status naturally rule out the need for information that is not a primary need (Ulfiana, 2013)

\section{Influence of hospital factors on the implementation of Relationship Marketing in Inpatients in Class III of Buleleng District Hospital.}

The results showed that there was an effect of the implementation of Relationship Marketing on hospital factors in Inpatients in Class III of Buleleng District Hospital. Hospital services in most types of in-patient health services use government BPJS guarantees of 95 respondents $(54.6 \%)$. On the variable value of patients in hospital services mostly good as many as 111 respondents (63.8\%). The test results of the influence that home services have eight times the opportunity to increase patient commitment and patient satisfaction in class III inpatients at Buleleng Hospital.

Patient value is the patient's view of the condition of the hospital, both from services, facilities, hospital rates which will later be a benchmark of hospital quality today and from this factor can affect patient satisfaction with the hospital.

Relationship Marketing covers the form of share value in services in hospitals, especially in the inpatient unit which can be in the form of share of wallet and share of mind and heart. Share of wallet is the first perception when choosing a product or service without thinking about financial or financial aspects. Share of wallet is a behavior that refers to customers who buy exclusively or mostly only one brand. While the share of mind and heart is having an emotional attachment to the brand, likes it more than others, and even loves the brand. Share value in hospital services has a role that is the hospital in providing services to exchange cultural values where the hospital must be able to provide comfort and friendliness to patients so that patients provide a good value or perception.

\section{Conclusion}

1. There is an effect of Relationship Marketing Implementation on Commitment in Inpatients in Class III of Buleleng District Hospital with a p-valuae value of 0.020 which means $<\alpha 0.05$ and Relationship Marketing 5 times has the opportunity to increase patient commitment

2. There is an Effect of Relationship Marketing Implementation on Satisfaction in Inpatients in Class III of Buleleng District Hospital with a p-valuae value of 0,000 which means $<\alpha 0.05$ and Relationship Marketing 5 times has the opportunity to increase patient commitment

3. There is an influence of patient characteristics on the implementation of Relationship Marketing in Inpatients in Class III of Buleleng District Hospital with a p-valuae value of 0,000 which means 
$<\alpha 0.05$ and 7 times the characteristics have the opportunity to increase patient commitment and satisfaction

4. There is an influence of hospital factors on the implementation of Relationship Marketing in Inpatients in Class III of Buleleng District Hospital. with p-valuae value of 0.040 which means $<\alpha$ 0.05 and hospital factors 8 times have the opportunity to increase patient commitment and satisfaction

\section{REFERENCE}

Aniroen, S. 1991. Policy of the Ministry of Health in Efforts to Improve Quality of Hospital Services. Medical World Stories Special Edition (71). Jakarta: Ministry of Health.

Anonymous. 2009. Law No. 44 of 2009 concerning Hospitals. http://www.perdhaki.org/content/uu-no44-tahun2009-ttg-hospital. [citation March 15, 2016]

Assauri, S. 2003. Management of Marketing Services. Volume 1. Jakarta: PT. Gramedia Main Library.

Brace, I. 2004. Design Questionnaire. London: Kogan Page Ltd.

Chan, S. 2003. Relationship Marketing: Marketing Innovations That Make Knees Customers. Jakarta: PT. Gramedia Main Library.

Donabedian, A. 1980. The Definition of Quality and Approaches to Its Assessment. Ann Arbor, MI: Health Administration Press.

Hurriyati., R. 2005. Marketing Mix and Consumer Loyalty. Bandung: Alfabeta.

Kotler and Keller. 2006. Marketing Management. Pearson: Education Inc.

Sulistiyani, R. 2009. Manajamen Human Resources. Yogyakarta: Graha Science.

Supriyanto, S and A. Djohan. 2011. Business and Health Research Methodology. Kalimantan: PT Grafika Wangi.

Tjiptono. F. 2004. Marketing Strategy. Second edition. Yogyakarta: Andi offset.

Wike 2009. Satisfaction of Inpatients Against Nurse Services at Tugurejo District Hospital Semarang. Thesis. Diponegoro University Postgraduate Program, Semarang.

Yuliarmi., R. 2007. Analysis of Factors That Affect Customer Satisfaction with the Service of the City of Denpasar. Bulletin of Economic Studies Vol. 12 No. 1

Zeithmal, V and Bitner M. 1996. Service Marketing. Singapore; The McGraw-Hill Companies, Inc. 